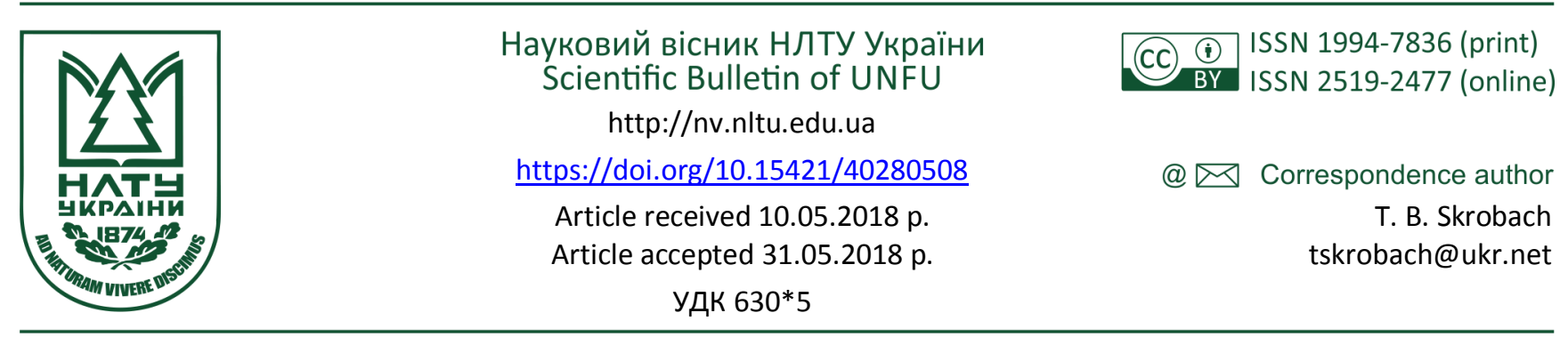

О. І. Микитчин, Т. Б. Скробач

Дрогобииький державний педагогічний університет ім. Івана Франка, м. Дрогобич, Україна

\title{
ТРАНСФОРМАЦІЯ ЛІСОВОГО ПОКРИВУ В БАСЕЙНОВІЙ ГЕОСИСТЕМІ РІЧКИ БЕРЕЖНИЦЯ
}

Розкрито особливості використання картографічного методу у ретроспективно-географічних дослідженнях природокористування та антропогенної трансформації лісового покриву. Обгрунтовано доцільність здійснення таких досліджень у розрізі басейнових геосистем малих річок. Проаналізовано підходи до вивченості трансформаційних процесів різними науковими школами та відзначено низку переваг картографічного методу дослідження, який реалізовується використанням геоінформаційних систем. Результати проведених досліджень відображено на низці картографічних моделей. Зокрема, для детального аналізу динаміки трансформації лісового покриву за даними обчислень, побудовано і проаналізовано картосхеми лісистості на чотири часові зрізи, а також зміни цих показників за період з 1880 р. до сучасності. Виявлено, що найменші зміни відбулися в перший період, коли вкриті лісом площі зменшувались для залучення цих земель у сільськогосподарський обробіток на незначній території нижньої частини досліджуваного річкового басейну. Відзначено, що другий період супроводжувався вирубуванням лісів внаслідок активнішого сільськогосподарського освоєння басейну та появи промислових об'єктів у Дашаві. З'ясовано, що третій період відзначився різновекторною трансформацією лісового покриву, адже поруч із вирубуванням лісу для поселенських та сільськогосподарських цілей у басейні відбувається активний розвиток сукцесійних процесів, які сприяють активній появі лісових масивів на покинутих землях. Встановлено, що трансформаційні процеси в лісовому покриві басейнової геосистеми Бережниці не відзначаються чіткими тенденціями, мають виключно антропогенний характер та напряму залежать від економічного розвитку поселень в її межах. Відзначено необхідність здійснення раціонального управління лісовими ресурсами шляхом сприяння збільшенню вкритих лісом площ у нижній частині басейну Бережниці та ведення ощадливого лісокористування у верхній та середній частинах.

Ключові слова: геоінформаційна модель; картографічний метод дослідження; басейнова система; лісовий покрив; лісистість; трансформаційні процеси.

Вступ. Унаслідок тривалої історії освоєння навколишнього середовища структура природних ландшафтів зазнала значних змін, що призвело до формування природно-господарських систем, у яких істотно знизилась здатність до саморегуляції, та виникнення комплексу еколого-географічних проблем. Лісистість території $\epsilon$ важливим показником екологічного стану, адже ліси відіграють важливу екологічно стабілізаційну роль завдяки водоохоронним, захисним, санітарно-гігієнічним та оздоровчим функціям. Важливою ознакою лісів є здатність до самовідновлення та саморегуляції, тому дослідження їх стану, кількості та прогнозування динаміки змін $\epsilon$ надзвичайно актуальним питанням сьогодення.

Найчастіше лісовий покрив аналізують у межах адміністративно-територіальних одиниць чи лісових господарств, за якими збирають інформацію про стан та наявність вкритих лісом площ. Проте, такий підхід не враховує системного принципу і не відображає реальної картини впливу лісу на стан інших компонентів геосфери. Найінформативнішою є оцінка лісового покриву в межах окремо взятих басейнових систем малих річок. Малі річки найтісніше пов'язані $з$ ландшафтом та

найшвидше відображають негативні процеси, які відбуваються у водозборі, оскільки виступають у ролі природних дренів сільськогосподарських угідь, є найбільш вразливими в разі нехтування природоохоронних вимог та найшвидше реагують на зміну площ лісових масивів.

Дослідження лісистості території потрібно розпочинати 3 ретроспективного вивчення антропогенної трансформації лісового покриву на основі різночасових картографічних моделей. Такий підхід дасть змогу більш обгрунтовано підійти до пропозицій системи заходів 3 оптимізації природокористування та перспектив освоєння досліджуваної території.

Питання аналізу перетворення територіальних комплексів досить широко вивчали наукові школи. Зокрема, вагомими $є$ здобутки ландшафтної екології, геоекології, моніторингу навколишнього середовища, геохімії та геофізики ландшафту, прикладної фізичної географії, урбоекології, гідроекології та екологічного руслознавства. Теоретико-методологічні основи дослідження трансформаційних процесів закладено у працях А. Д. Арманда, . П. Гавриленка, С. А. Грекова, М. Д. Гродзинського, Е. А. Клементової, I. П. Ковальчука,

Інформація про авторів:

Микитчин Оксана Іванівна, канд. геогр. наук, ст. викладач, кафедра екології та географії. Email: omykytchyn@ukr.net Скробач Тарас Богданович, канд. с.-г. наук, доцент, кафедра екології та географії. Email: tskrobach@ukr.net Цитування за ДСтУ: Микитчин О. І., Скробач Т. Б. Трансформація лісового покриву в басейновій геосистемі річки Бережниця. Науковий вісник НЛТУ України. 2018, т. 28, № 5. С. 39-43.

Citation APA: Mykytchyn, O. I., \& Skrobach, T. B. (2018). The forest cover transformation in the basin geosystem of the Berezhnytsya river. Scientific Bulletin of UNFU, 28(5), 39-43. https://doi.org/10.15421/40280508 
І. Б. Койнової,

Ф. Н. Милькова,

А. Г. Потапової, А. М. Третяка, П. Г. Шищенка. Трансформаційні процеси у землекористуванні вивчали Б. М. Данилишин, М. А. Хвесик, І. П. Ковальчук, Т. О. Свсюков, С. А. Іванов, М. А. Петровська, П. Вербург, А. Вальз, Д. Лісіо, П. Ксорба (Berliant, 1986; Berliant, Serbeniuk \& Tikunov, 1987; Haskevych, 2001; Zhydachiv, 1998; Drohobych, 1998; Kovalchuk, 1997; Obodovskyi, 2001; Danylyshyn, et al., 1999; Sakal, 2005; Salishhev, 1982).

Найбільш звиклий для географа спосіб моделювання - зображення досліджуваного явища на карті і проведення подальшого дослідження, користуючись цією моделлю (Arkhipova, et al., 2002). Основи картографічного методу дослідження розробив проф. К. Саліщев (Salishhev, 1982), уточнив і розвинув проф. О. Берлянт (Berliant, 1986). Історичні карти, як джерело інформації про територію України, дослідив Р. Cocca (Sossa, 2007). Сучасні досягнення тематичного картографування роблять цей спосіб досить перспективним, однак досі значно більше уваги приділяли насиченню карт інформацією, ніж отриманню на їх основі нових даних. Поза сумнівом, найшвидше виконання цього пробілу надзвичайно актуальне і потребує розроблення відповідних методів аналізу карт. Пізнання включає отримання за картами якісних відомостей і кількісних характеристик явищ і процесів, вивчення взаємозв'язків і взаємозалежностей у геосистемах, їхньої динаміки та еволюції, установлення тенденцій розвитку та прогноз майбутніх станів геосистем (Karpik, 2004).

Методика дослідження. Для оцінювання трансформаційних процесів лісового покриву використовували топографічні карти 1880, 1922, 1945 рр. та космознімки QuickBird 2009 p. Найкраще можна зіставити карти однакових масштабів, проекції та системи координат (Arkhipova, et al., 2002). Проте найчастіше, для визначення трансформаційних змін використовують карти, побудовані через значні проміжки часу, кожна з яких має свій, відповідний часу створення, спосіб зображення земної поверхні, тому дуже часто доводиться аналізувати карти 3 різними умовними позначеннями. Ускладнює процедуру порівняння різночасового матеріалу і власне сам картографічний матеріал, адже карти створювали на папері, що з часом зазнавав деформацій (під впливом факторів навколишнього середовища), тому важливою умовою для коректного аналізу трансформаційних змін $є$ надійна прив'язка карт як до системи координат, так і між собою. У технічному плані цю процедуру дає змогу здійснити програмний модуль Georeferencing у програмному продукті ArcGIS 9.0 (Berezhnytsia, 2004).

Кінцевим продуктом такого аналізу, зазвичай, є карта динаміки (змін) досліджуваного географічного об'єкта. Однак, застосовуючи геоінформаційні технології, практично завжди спочатку отримують деякі проміжні зображення і так звану таблицю (матрицю) переходів, де зафіксовані всі відмінності між зіставлюваними зображеннями (Bogomolov, 1963).

Трансформаційні процеси лісового покриву досліджували в басейновій системі Бережниці на рівні підбасейнів тальвежної мережі різного порядку. Річка Бережниця - притока Дністра, мала річка Прикарпаття, яка бере початок у Долинському р-ні Івано-Франківської обл. та протікає територією Стрийського та Жидачівського районів Львівської області.
Результати дослідження та їх обговорення. Розвиток рослинності басейну пов'язаний із процесом формування лісової зони Європи, початок якого припадає на ранній пліоцен, коли ця територія звільнилася від моря. Значний відбиток на розвиток рослинності мало четвертинне зледеніння. Після льодовика виникли нові умови, які сприяли розвиткові широколистих лісів і лучної рослинності (Sakal, 2005). Усе Передкарпаття було вкрите лісовою рослинністю, переважно дубовими i грабовими лісами. Великі зміни у природній рослинності зробила людина. Вона винищила лісову і трав'яну рослинність, а їх місце зайняли культурні рослини. На цей час на території басейну ліси займають підвищені простори, невеликими острівцями на непридатних для оранки землях трапляється лучна рослинність. Загалом флора налічує понад 1000 видів насінних, вищих спорових рослин (Berezhnytsia, 2004).

Ліси, які розміщені в басейні Бережниці, переважно $\epsilon$ широколистяними, рідше мішаними. Панівними типами лісів є грабові діброви та бучини 3 домішкою берези і вільхи та хвойні угруповання 3 переважанням ялини. Часто трапляються липа серцелиста, горобина та ялиця. Основними лісотвірними породами є дуб скельний, ялина звичайна, бук лісовий, граб, в'яз, клен-явір та липа, береза, осика, черешня, яблуня дика, груша звичайна як домішки (Sakal, 2005).

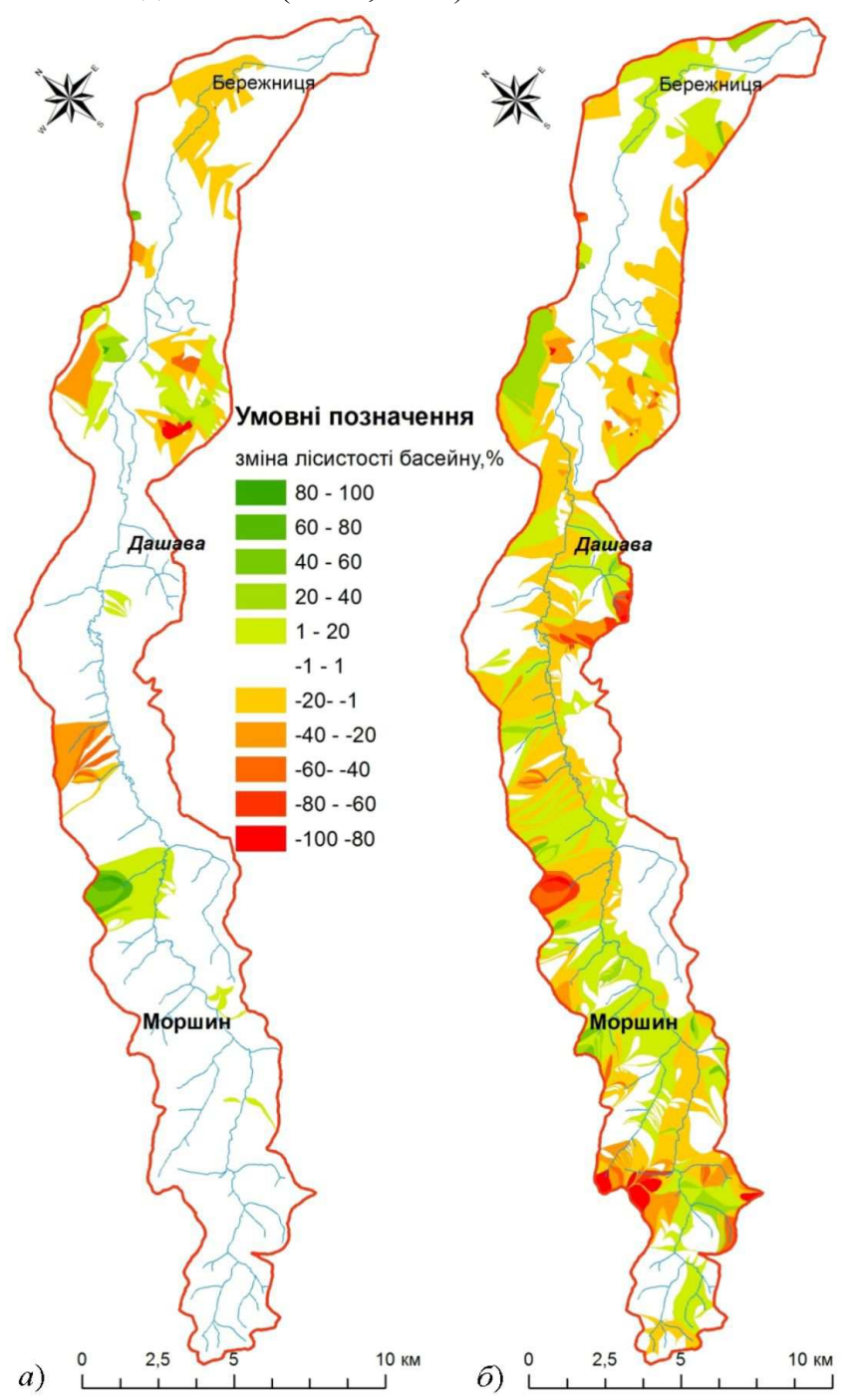

Рис. 1. Зміна лісистості басейнової системи р. Бережниця впродовж: а) 1880-1914 рр.; б) 1914-1945 pр. (у розрізі підбасейнів) 
Результати моделювання трансформації лісового покриву показали, що в досліджуваному басейні найменші зміни відбулися в перший обліковий період (1880-1914 pр., 34 роки) (рис. 1,a). Зокрема, зміна лісистості в нижній частині басейну відбулася внаслідок залучення до сільськогосподарського обробітку заболочених земель, чому сприяло розширення меліоративної мережі на цій території. Збільшилася лісистість поблизу хутора Пила та села Ганівці. Вона зменшилась в наступні періоди.

Більші зміни відбулися упродовж другого облікового періоду (1914-1945 рр., 31 рік) (рис. 1,б). Найгостріше позначилися зміни у верхній частині басейну, де активно вирубували лісові угіддя. Так, поблизу хутора Смоляний лісові угіддя переводилися в категорію оброблюваних земель, в околицях смт Дашава відбувалися подібні процеси, які разом із ростом селища та його промисловості призводили до зменшення площ лісів (Lisio \& Filippo, 2010; Verburg, et al., 2010). Збільшення сільськогосподарських угідь шляхом зменшення площ лісових угідь спостерігається і в нижній частині (за винятком околиць сіл Бережниця та Заболотівців, де цей процес ускладнюється заболоченням території, внаслідок чого на цій території збільшується кількість лісових угідь).

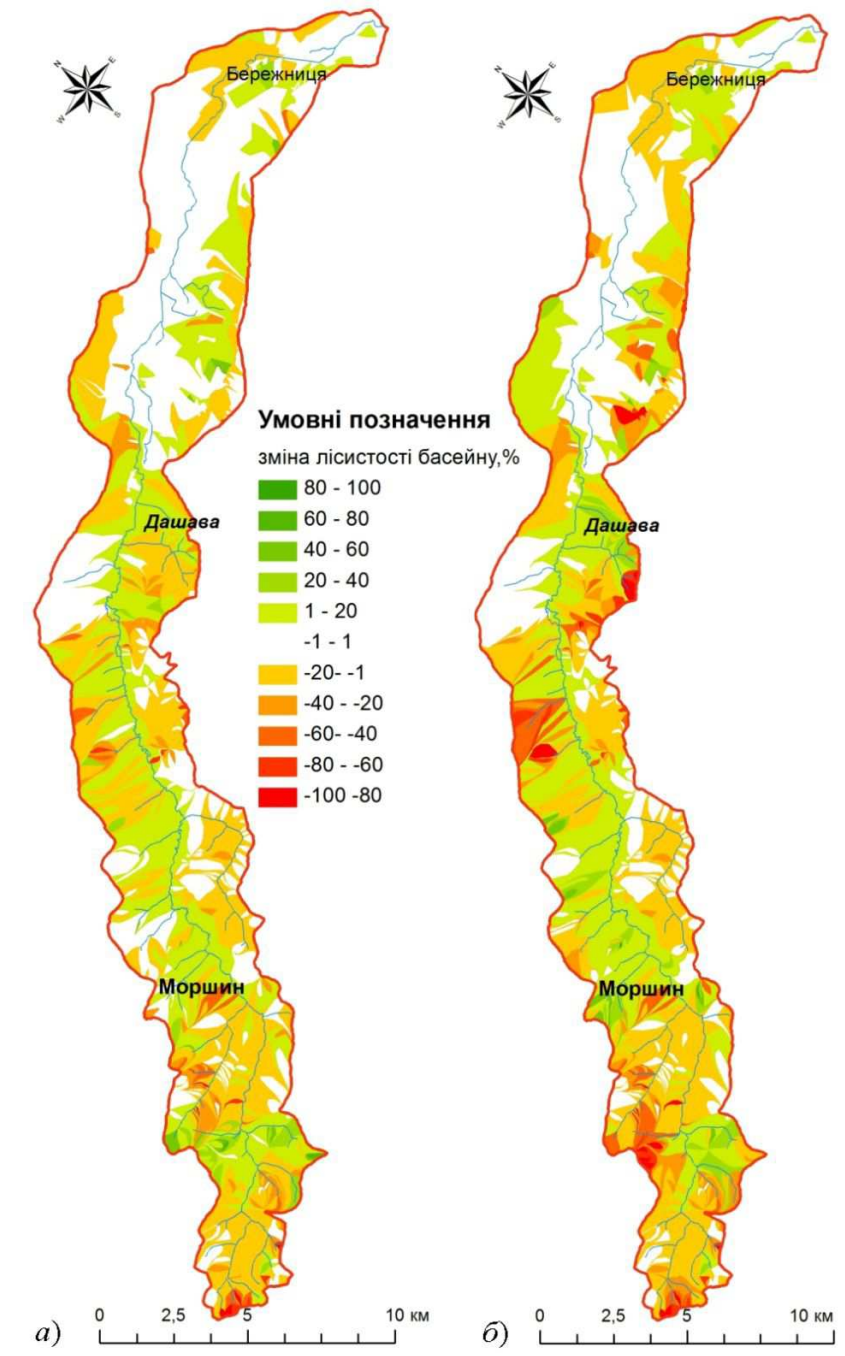

Рис. 2. Зміна лісистості басейнової системи р. Бережниця впродовж: а) 1945-2009 pр.; б) 1880-2009 pp. (у розрізі підбасейнів)

У третьому обліковому періоді (1945-2009 pp., 64 роки) (рис. 2,a) значні зміни лісистості відбулися, в основному, в підбасейнах 1-2 порядків. Значні вирубування лісів 3 промисловою метою відбувалися у верхній течії. Зменшення лісистості у цій частині басейну спричинило створення трьох дачних поселень (у Долішненській сільській раді). Поруч із зниженням лісистості, в басейні річки Бережниця відбуваються зворотні процеси, які однаковою мірою характерні всій досліджуваній території (Csorba et al., 2009; ESRI ArcGIS 9, 2004). Це стається внаслідок активізації сукцесійних процесів на покинутих сільськогосподарських угіддях. У цьому басейні сукцесійні процеси відбуваються з різних причин і мають часом протилежний характер. Так, внаслідок зменшення ролі хуторів та невеликих сіл в економічному розвитку регіону та, відповідно, відтоку з них робочої сили, території поблизу цих поселень заросли деревною рослинністю. Зокрема, найактивніше такі процеси розвиваються поблизу х. Смоляний. Збільшення лісистості відбувається поблизу багатьох населених пунктів через заростання покинутих малопродуктивних земель сільськогосподарського призначення, оскільки зросла інтенсивність використання орних земель. Такі ж процеси відбулись внаслідок зменшення поголів'я ВРХ, яке спостерігається в усіх населених пунктах цього регіону, що значно збільшило частку необроблюваних земель (Khvesyk, Holian \& Krysak, 2008; Walz, Ariane, 2006). Сумарну зміну лісистості басейнової системи р. Бережниця впродовж 1880-2009 pр. (у розрізі підбасейнів) зображено на рис. 2,б.

Серед трав'яних формацій на рівнині панівне місце належить лукам (понад 11 \% басейну Бережниці), серед яких найпоширенішими $є$ післялісові суходільні луки. У специфічних умовах збереглися ділянки лісостепової рослинності (у вигляді остепнених луків). Найнижчі перезволожені ділянки річкових заплав вкриті болотистими і торф'янистими луками $(1,5$ \% від досліджуваної території). У заплаві Бережниці ростуть такі злакові рослини: костриця лучна, вівсянець лучний, лисохвіст лучний, стоколос безостий, тимофіївка лучна, тонконіг лучний, осот прибережний, підмаренник болотний, королиця звичайна, зозулин цвіт (Kovalchuk, Zinko \& Kholodko, 1992). На підвищених місцях трапляються: пахуча трава, медова трава, осоки (звичайна, жовта, біла), королиця звичайна, китятки чубаті, подорожник ланцетоподібний. Болотисті луки багаті на такі злакові, як: очеретянка звичайна, лепешняк плавучий і великий, комиш лісовий, хвощі (річковий і болотний), осоки (жовта, просяна та інші) і дрібні злаки (медова трава м'яка, моління прибережна), пухівка вузьколиста, ситник розлогий. Відомі також замшілі торф'янисті луки 3 пануванням мохового покриву зі сфагнових мохів. Різноманітність культурної рослинності визначається багатогалузевою спеціалізацію сільськогосподарського виробництва (Yevsiukov \& Martyn, 2010; Ivanov, 2007).

Висновки. Аналізуючи моделі зміни лісистості басейнової системи Бережниці протягом майже 130-річного періоду, з'ясовано, що більша частина лісового покриву зазнала змін. Незмінними залишилися тільки ті басейни, у структурі яких не було лісу, або ті частини лісових угідь, які розташовані на великих відстанях від населених пунктів. Упродовж цих років ліс вирубували 3 різною метою: промисловою, для створення нових поселень (хутір Смоляний та дачні поселення Долішненської сільської ради), для розширення сільськогосподарських угідь. Також відбувалися зворотні процеси, внаслідок яких розвивалися постантропогенні сукцесії і покинуті землі заростали деревною рослинністю. 


\section{Перелік використаних джерел}

Arkhipova, N. A., Kocheria, A. G., Lebedeva, I. P., \& Safonova, K. I. (2002). Gidroekologiia: kolichestvennaia otcenka postupleniia $v$ vodnye obekty zagriazniaiushhikh veshhestv ot rassredotochenikh istochnikov. Inzhenernaia ekologiia, 1, 27-41. [In Russian].

Berezhnytsia. (2004). Prohrama dii z okhorony dovkillia dlia hromad, roztashovanykh v baseini $r$. Berezhnytsia. Materialy Rehionalnoho ekolohichnoho tsentru "RETs-Kyiv". Kyiv. 19 p. [In Ukrainian].

Berliant, A. M. (1986). Obraz prostranstva: karta i informatciia. Moscow: Mysl. 240 p. [In Russian].

Berliant, A. M., Serbeniuk, S. N., \& Tikunov, V. S. (1987). Printcipy i metodika ispolzovaniia geograficheskikh kart dlia formirovaniia bankov danniakh. Banki geograficheskikh dannykh dlia tematicheskogo kartografirovaniia, 38-47. [In Russian].

Bogomolov, L. A. (1963). Topograficheskoe deshifrirovanie prirodnogo landshafta na aerosnimkakh. Moscow: Gosgeoltekhizdat. 196 p. [In Russian].

Csorba, Péter, \& Szabó, Szilárd. (2009). Degree of human transformation of landscapes: a case study from Hungary. Hungarian Geographical Bulletin, 58(2), 91-99.

Danylyshyn, B. M., Dorohuntsov, S. I., Mishchenko, V. S., Koval, Ya. V., Novotarov, O. S., \& Palamarchuk, M. M. (1999). Pryrodno-resursnyi potentsial staloho rozvytku Ukrainy. Kyiv: RVPS Ukrainy. 716 p. [In Ukrainian].

Drohobych. (1998). Osnovni pokaznyky tekhnichnoi ekspluatatsi osushnykh system i vykorystannia osushnykh zemel v Drohobytskomu upravlinni osushnykh system. Derzhavnyi komitet Ukrainy po vodnomu hospodarstvu. Lviv. 41 p. [In Ukrainian].

ESRI ArcGIS 9. (2004). ArcMap. Rukovodstvo polzovatelia - Redlands: ESRI PRESS. 558 p. [In Russian].

Haskevych, V. H. (2001). Vplyv osushennia na vlastyvosti ta vykorystannia gruntiv Maloho Polissia. Visnyk Lvivskoho ahrarnoho un-tu. Seriia "Ahronomiia", 5, 122-127. [In Ukrainian].

Ivanov, Ye. A. (2007). Landshafty hirnycho-promyslovykh terytorii. Lviv: Vyd. tsentr LNU imeni Ivana Franka. 334 p. [In Ukrainian].
Karpik, A. P. (2004). Metodologicheskie i tekhnologicheskie osnovy geoinformatcionnogo obespecheniia territorii. Novosibirsk: SGGA. 260 p. [In Russian].

Khvesyk, M. A., Holian, V. A., \& Krysak, A. I. (2008). Instytutsionalni transformatsii ta finansovo-ekonomichne rehuliuvannia zemlekorystuvannia v Ukraini. Kyiv: Kondor. 511 p. [In Ukrainian].

Kovalchuk, I. P. (1997). Rehionalnyi ekoloho-heomorfolohichnyi analiz. Lviv. 438 p. [In Ukrainian].

Kovalchuk, I. P., Zinko, Yu. V., \& Kholodko, L. P. (1992). Ekolohoheomorfolohichni problemy intensyvno-meliorovanykh baseiniv malykh rik. Ekolohichni aspekty osushuvalnykh melioratsii na Ukraini, 107-108. [In Ukrainian].

Lisio, Di, \& Antonio and Russo, Filippo. (2010). Thematic Maps for Land-Use Planning and Policy Decisions in the Calaggio Stream Catchment Area. Journal of Maps, 68-83. https://doi.org/10.4113/jom.2010.1105

Obodovskyi, O. H. (2001). Hidroloho-ekolohichna otsinka ruslovykh protsesiv (na prykladi richok Ukrainy). Kyiv: Nika-tsentr. 274 p. [In Ukrainian].

Sakal, Ye. (2005). Heohrafiia Stryishchyny. Stryi: Shchedryk. 172 p. [In Ukrainian].

Salishhev, K. A. (1982). Kartovedenie. Moscow: Izd-vo MGU. 408 p. [In Russian].

Sossa, R. I. (2007). Istoriia kartohrafuvannia terytorii Ukrainy. Kyiv: Lybid. 336 p. [In Ukrainian].

Verburg, P., van Berkel, D., van Doorn, A., van Eupen, M., \& van den Heiligenberg, H. (2010). Trajectories of land use change in Europe: a model-based exploration of rural futures. Landsc. Ecol, 27(2), 217-232. https://doi.org/10.1007/s10980-009-9347-7

Walz, Ariane. (2006). Land Use Modelling for an Integrated Approach to Regional Developmentin the Swiss Alps. Zürich. 185 p.

Yevsiukov, T. O., \& Martyn, A. H. (2010). Kontseptualni zasady bezpechnoho zemlekorystuvannia. Zemleustrii ta kadastr, 1, 26-29. [In Ukrainian].

Zhydachiv. (1998). Osnovni pokaznyky tekhnichnoi ekspluatatsii osushnykh system i vykorystannia osushnykh zemel v Zhydachivskoти upravlinni osushnykh system. Derzhavnyi komitet Ukrainy po vodnomu hospodarstvu. Lviv. 39 p. [In Ukrainian].

О. И. Мыкытчын, Т. Б. Скробач

Дрогобычский государственный педагогический университет им. Ивана Франко, г. Дрогобыч, Украина

\section{ТРАНСФОРМАЦИЯ ЛЕСНОГО ПОКРОВА БАССЕЙНОВОЙ ГЕОСИСТЕМЫ РЕКИ БЕРЕЖНИЦА}

Раскрыты особенности использования картографического метода в ретроспективно-географических исследованиях природопользования и антропогенной трансформации лесного покрова. Обоснована целесообразность осуществления таких исследований в разрезе бассейновых геосистем малых рек. Проанализированы подходы к изученности трансформационных процессов различными научными школами и отмечен ряд преимуществ картографического метода исследования, который реализуется использованием геоинформационных систем. Результаты проведенных исследований отражены в ряде картографических моделей. В частности, с целью детального анализа динамики трансформации лесного покрова по данным вычислений, построены и проанализированы картосхемы лесистости на четыре временные срезы, а также изменения этих показателей за период с 1880 года до наших дней. Обнаружено, что наименьшие изменения произошли в первый период, когда лесопокрытые площади уменьшались для привлечения этих земель в сельскохозяйственную обработку на незначительной территории нижней части исследуемого речного бассейна. Отмечено, что второй период сопровождался вырубкой лесов вследствие более активного сельскохозяйственного освоения бассейна и появления промышленных объектов в Дашаве. Выяснено, что третий период отметился разновекторной трансформацией лесного покрова, ведь рядом с вырубкой леса для поселенческих и сельскохозяйственных целей в бассейне наблюдается активное развитие сукцессионных процессов, которые способствуют активному появлению лесных массивов на заброшенных землях. Установлено, что трансформационные процессы в лесном покрове бассейновой геосистемы Бережницы не отличаются четкими тенденциями, имеют исключительно антропогенный характер и напрямую зависят от экономического развития поселений в ее пределах. Отмечена необходимость осуществления рационального управления лесными ресурсами путем содействия увеличению лесопокрытой площади в нижней части бассейна Бережницы и ведения экономного лесопользования в верхней и средней частях.

Ключевые слова: геоинформационная модель; картографический метод исследования; бассейновая система; лесной покров; лесистость; трансформационные процессы.

O. I. Mykytchyn, T. B. Skrobach Drohobych State Pedagogical University named after Ivan Franko, Drohobych, Ukraine

\section{THE FOREST COVER TRANSFORMATION IN THE BASIN GEOSYSTEM OF THE BEREZHNYTSYA RIVER}

The features of the cartographic method application in the retrospective-geographical research for the nature use and anthropogenic transformation of forest cover are described in the article. The feasibility of conducting such studies in the context of small river basin geosystems is substantiated. The approaches to the study of transformation processes in different scientific schools are analysed. A number of advantages for the cartographic research method, which is implemented using the geoinformation systems, 
is noted. The results of the carried research are shown in a number of cartographic models. In particular, the skeleton maps of forest cover percentage for four time slices (samples), as well as changes in these indicators for the period from 1880 to the present, were constructed and analysed for the purpose of a detailed analysis in the dynamics of forest cover transformation using the calculations data. The slightest changes were found to occur in the first period, when forest cover areas were reduced because of the use these lands for agricultural cultivation within a small area in the lower part of the studied river basin. It was noted that the second period was accompanied by deforestation due to more active agricultural development in the basin and the emergence of industrial facilities in Dashava. It was revealed that the third period was characterized by the multivectoral transformation in the forest cover, as an active development of successional processes promoting the active appearance of forest massifs on abandoned lands was noted together with the felling of the forest for construction and agricultural purposes observed in the basin. It was established that transformation processes in the forest cover of the Berezhnytsia river basin geosystem do not have the clear tendencies; they are solely anthropogenic and directly dependent on the economic development of settlements within their boundaries. The need for the rational forest resources management by promoting the increase of forest cover areas in the lower part of the Berezhnytsia river basin and the economical use of the forests in the upper and middle parts was noted.

Keywords: geoinformation model; cartographic research method; basin system; forest cover; forest area; transformation processes. 